\title{
Analysis of possible risks in introducing congestion charging and carpooling measures in Zagreb
}

\author{
M. Slavulj, I. Grgurević \& J. Golubić \\ Faculty of Transport and Traffic Sciences, University of Zagreb, Croatia
}

\begin{abstract}
Today citizen mobility represents both an interesting research area and a subject for the introduction of structural dynamic plans. There are a number of international technical and scientific projects which analyze and suggest mobility solutions for participants in urban transport. The scope of research includes the part related to problems in the execution of structural transport measures in the City of Zagreb. Problem identification refers to partial measures such as measures of mobility management (congestion charging and carpooling system). The problems are reflected through the following types of risk: technical and technological, organizational, economic, regulatory, political, etc. Each of these risks has a number of features that require a comprehensive analysis in order to implement measures to improve traffic flow in cities. One of the major problems is the absence of adequate legislation and determination in making such measures that will affect the improvement of traffic across the transport network of the city of Zagreb. To achieve a measure of mobility in the city, it is necessary to achieve a constructive dialogue with all the stakeholders who are included in the observed measure. Special attention should be paid to the legitimate needs of citizens, and proposed solutions through elaborate public discussions.
\end{abstract}

Keywords: citizen mobility, mobility management, congestion charging, carpooling, external costs.

\section{Introduction}

The City of Zagreb, being the capital with 804,200 inhabitants (in 2008) and with about 555,000 registered vehicles (in 2008), has recorded a significant 
increase in motorization levels in the past ten years. Analysis of the data generating personal vehicle travels shows that after 1996, the trend of increase in motorization levels is constantly growing, more so than registered in the rest of Croatia. The data of 500 vehicles on 1000 inhabitants for the City of Zagreb in 2008, shows that Zagreb has reached other European cities in motorization levels. High motorization levels and an increase in the standard of inhabitants have significantly affected the modal split in the City of Zagreb. It is evident that in the modal split of motorized journeys in 2003, there was a substitution in the share of public transport journeys and personal vehicle journeys in comparison to 1990. While in 1990, the share in public transport journeys was $55 \%$, personal vehicles $44 \%$ and others $1 \%$, in 2003 , the modal split consisted of $40 \%$ public transport journeys, an increase in the use of personal vehicles amounted to $59 \%$ and others remained at $1 \%$.

The analysis of the stated data (estimation by the Statistical Yearbook of the City of Zagreb) correlates with the state and quantity of traffic in the central part of the City of Zagreb [1].

The number of personal vehicles arriving in the city center has grown enormously, which has caused the concentration of traffic volume exceeding the capacity of the existing transport network and which causes frequent congestion with all the negative effects. It causes daily peak hour load for personal vehicle journeys, traffic congestion and loss of time through extended time of travel to destination. It also generates negative effects on the environment (noise, air pollution and others).

\section{Mobility management}

The City of Zagreb should have set two major goals. First, to reduce traffic congestion and overload of the traffic system, which appear daily on the road network at peak and other hours. Second, to protect the environment by reducing emissions. On the basis of the Law on Air Protection category according to the degree of air pollution can be classified into three categories. In some areas the air is a Category II or moderately polluted air, and occasionally the third category, or over-polluted air (exceeded the tolerance levels of air quality for one or more pollutants).

The absence of a integer strategy in Zagreb and partial work on some measures of mobility management emphasizes the additional traffic problems. The duration of congestion increases, which results in an increase in travel time for two or more times on arterial roads of the City of Zagreb.

Congestion charging belongs to the transportation demand management (TDM) strategies and it cannot be considered in isolation (Table 1). Complementary strategies with congestion charging for the City of Zagreb are: management of parking rates and improvment of public transport. Long term practice of unauthorized and illegal sales of annual parking tickets in the first zone in Zagrebparking (parking operator in Zagreb) reflected to the effect which 


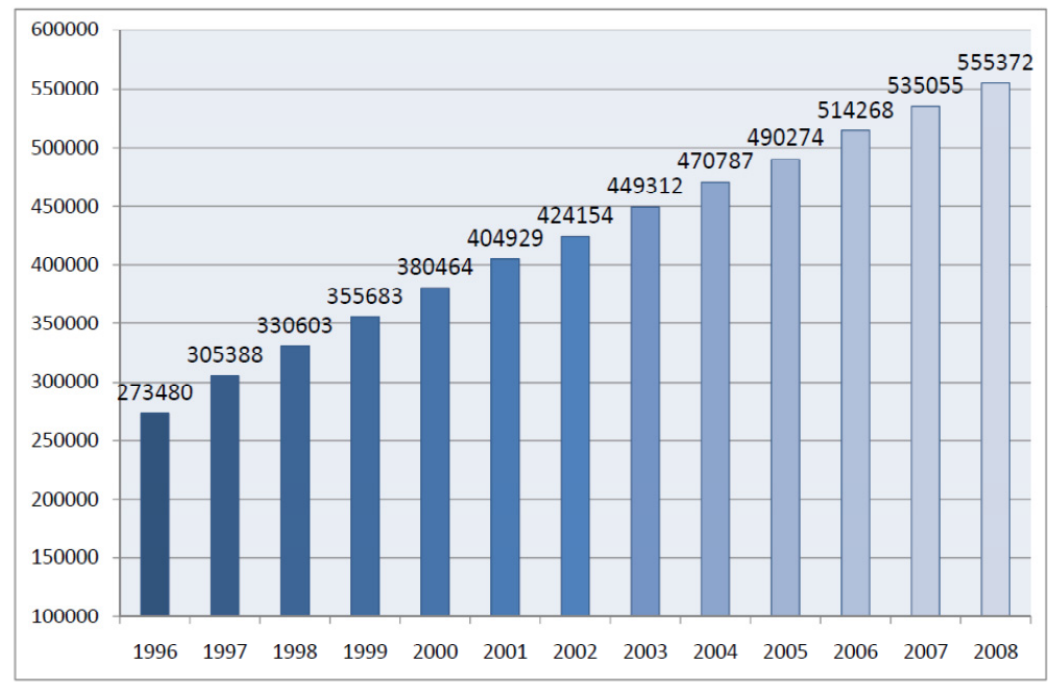

Figure 1: $\quad$ Number of motor vehicles in Zagreb since 1996 until 2008 [2].

should contribute to reducing the number of vehicles in the center. Cars are often looking half an hour for parking space and thus further load the network due to unsufficient number of garages that would attract traffic underground and ensure freer movement of traffic in the center. Improvement in public transport could be done: by decreasing and respecting tram and bus headways, in peak hours ensuring sufficient capacity, introducing carpooling and car sharing systems, by installing systems of public bicycles in the city center, etc. The railway in Zagreb is ideally placed (in the heart of the city), and is underutilized in suburban transport. By increasing the capacity of trains and setting up a 15 minute headway, the number of passengers and level of service could increase significantly.

For the operation of the tram traffic is used $116346 \mathrm{~m}$ of track, on which every working day is in use 193 tram motor cars and 41 trailers. In the morning peak hours on the tram lines where trams operate with other traffic are generated average travel speed is between 12 and $16 \mathrm{~km} / \mathrm{h}$, and the individual sections (parts of the Savska road) trams speed are even lower than $10 \mathrm{~km} / \mathrm{h}$.

The entire bus traffic takes place at 134 day and four night lines. In the morning peak hours on the bus network in the urban parts of the city center are generated average travel speeds between 15 and $25 \mathrm{~km} / \mathrm{h}$, and on the individual sections speed of vehicles is also lower than $10 \mathrm{~km} / \mathrm{h}$.

According to the data from Croatian Raliways (Department for passenger urban transport) daily in Zagreb is realized a total of 360 suburban train ride (including local) with the arrival or departure at the Zagreb Main Station, and the every day is carried 100,000 passengers. Table 2 shows a continual passenger 
Table 1: $\quad$ Examples of transportation demand management [3].

\begin{tabular}{|c|c|c|c|}
\hline $\begin{array}{c}\text { Improve transport } \\
\text { options }\end{array}$ & $\begin{array}{l}\text { Economic } \\
\text { measures }\end{array}$ & $\begin{array}{l}\text { Smart growth and } \\
\text { land use policies }\end{array}$ & Other programs \\
\hline $\begin{array}{l}\text { Public transit } \\
\text { improvements } \\
\text { Walking and cycling } \\
\text { improvements } \\
\text { Mobility management } \\
\text { marketing programs } \\
\text { Rideshare /commute trip } \\
\text { reduction programs } \\
\text { HOV priority lanes } \\
\text { Flextime/telecommuting } \\
\text { Carsharing/Carpooling } \\
\text { services } \\
\text { Taxi service improvements } \\
\text { Guaranteed ride home } \\
\text { program } \\
\text { Shared bicycle services }\end{array}$ & $\begin{array}{l}\text { Congestion pricing } \\
\text { Distance-based fees } \\
\text { Commuter } \\
\text { financial incentives } \\
\text { Parking pricing } \\
\text { Parking regulations } \\
\text { Fuel tax increases } \\
\text { Transit } \\
\text { encouragement }\end{array}$ & $\begin{array}{l}\text { Smart growth } \\
\text { Transit-oriented } \\
\text { development } \\
\text { Location-efficient } \\
\text { development } \\
\text { Parking management } \\
\text { Car-free planning } \\
\text { Traffic calming } \\
\text { Transport planning } \\
\text { reforms }\end{array}$ & $\begin{array}{l}\text { School and } \\
\text { campus transport } \\
\text { management } \\
\text { Freight transport } \\
\text { management } \\
\text { Tourist transport } \\
\text { management }\end{array}$ \\
\hline
\end{tabular}

Table 2: $\quad$ Passengers increase in urban rail commuting.

\begin{tabular}{|c|c|}
\hline Year & Passengers \\
\hline 2006. & 28.603 .564 \\
\hline 2007. & 44.428 .692 \\
\hline 2008. & 52.449 .760 \\
\hline 2009. & 53.908 .140 \\
\hline
\end{tabular}

increase in urban rail commuting. Period since 2006. until 2009. was the impressive $88 \%$, which is definitely a continuation of positive trends.

\section{Analysis of possible risks in introducing congestion charging}

\subsection{Technical and technological}

Analyzing the possible technical and technological solution vignettes, ANPR (Automatic Number Plate Recognition), DSCR (Dedicated Short Range Communication) and GNSS (Global Navigation Satellite System) we come to the conclusion that currently for the Zagreb is optimal solution to introduce a 
vignette. Vignettes could enable a quick and easy application, and on the other hand avoid investing in expensive infrastructure that requires ANPR or DSCR solutions. To solve problems on the whole city area of a long term solution should be the introduction of payment by GNSS, which will also need a consensus on a national level.

\subsection{Business system}

Running a transport solution is no different to running any other type of business. Essentially it is dealing with customers, their records, some form of transaction, banking, web and telephone based interfaces, accounts, reconciliation and finally reporting on the performance of the business. The way that these processes are glued together is effectively the business system and it would normally be expected that this would be fully automated with minimal manual intervention. The system would also be expected to provide all the necessary reporting information as well as providing a platform for dealing with customer care. The following design issues need to be considered:

- Identify each integration component;

- Identify communications between components;

- Identify user interaction with each component;

- Propose a network topology and communications infrastructure;

- Establish availability, fault tolerance, and load balancing requirements;

- Incorporate security requirements.

It is important that the skill sets for the managing the business system design is available in house before the procurement process is begun. There are a number of procurement routes that can be adopted ranging from a single turnkey contractor providing the design, integration, supply and operation of the system through to having separate commissions for each of the individual elements. Insufficient cooperation between involved partners could have high potencial impact for implementation process.

\subsection{Legislation}

Write legislation that will be defined by everything related to the implementation of congestion charging and ensure the adoption of the Zagreb City Council.

\subsection{Political}

The opinion of local politicians and their subsequent actions are of paramount importance for the successful implementation of urban road pricing schemes. This is one common experience of all cities implementing or attempting to implement urban road pricing. They directly or indirectly determine whether or not the pricing scheme will be introduced as well as the speed of the policy implementation process [4]. 
In this situation a political champion or figurehead, who takes ownership of the congestion charging concept, clearly facilitates the implementation process. However, unlike the officials involved in the preparation of any scheme, politicians depend on re-election, and the fear of losing elections by promoting road user charging holds many politicians back. Even where there is strong enough political support to go ahead with charging plans, politicians can easily be disheartened if they find that public support is eroding in the run-up to the scheme introduction [5]. One way of divorcing the road pricing issue from elections is to hold a referendum. It should be noted, though, that a referendum just before the last steps of the scheme introduction is very likely to hit the lowest level of support, and therefore runs the greatest risk of failure. An alternative to an early referendum is the Stockholm approach: here the referendum was held around one year after a congestion charging scheme was implemented "on a trial basis". Whilst this approach carries a large financial risk, it provides the best chances for the referendum to be won, since it has been shown that public support for a charging scheme increases again once it is up and running and people start to feel its benefits. In that respect the public opinion is the most important source of information for the politicians in the implementation process. Thus, presenting not only the benefits of the scheme to the politicians, but also pointing out where the public agrees with the road pricing scheme may increase political acceptability considerably [6]. Final decisions on measures to adopt will be reached by the Zagreb City Council.

\subsection{Economic and financial}

Following positive political decisions fundings to ensure the introduction of congestion charging are not questionable. Billing system should be designed in a way that does not make losses, it should prove cost-benefit analysis. Excess funds should be allocated to improve the public transport. The main objective of the City of Zagreb as well as what is said is not making profits, but also reduce congestion and the environment by reducing emissions.

\subsection{Acceptability problems}

The term "acceptability" describes the prospective judgement of measures to be introduced in the future. Acceptability refers to the attitude of relevant stakeholders towards congestion charging. Relevant stakeholders which attitudes can be researched are: 1) the citizens; 2) residents; 3) politicians and decision makers; 4) business subjects. Potential users could opppose charging and researching of acceptability is very important for reducing risks. Communication campaign and other activities should be taken in the form of:

- Interviews, workshops and round tables targeted at major stakeholders;

- Promotional material and awareness raising activities;

- Public presentations and discussions with different stakeholders (e.g. citizens of the relevant areas, shopkeepers, etc.). 
Awareness of the problems of traffic congestion in Zagreb is shown in Figure 2, where $98 \%$ of respondents answered affirmatively.

The idea of introducing an "Eco-zone" in the center of town where the driver will pay a traffic congestion charge is supported by $62 \%$ of citizens and $70 \%$ of business subjects in Zagreb (Figure 3).

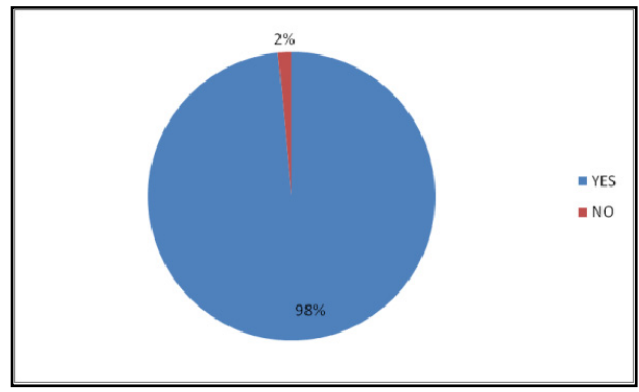

Figure 2: $\quad$ Awareness of traffic congestion in Zagreb.

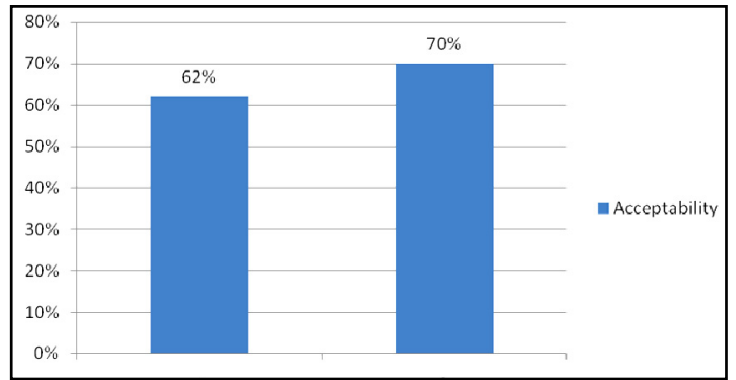

Figure 3: Level of support about paying traffic congestion for Zagreb.

\subsection{Determination of the charging zone}

Determination of the charging zone is very complex work, where we need to determine the size and its boundaries. The proposal for boundaries is to be in the City center. Zone should be logically placed so that the enables essential communications. Problems typically occur around a group of vehicles that would be exempt from charges. Surveys showed that the most citizens is for the introduction of charging only in the center, not in wider area of the City of Zagreb.

\section{Analysis of possible risks in introducing carpooling system}

The modal split is constantly shifting in favour of personal cars and thus the city center is faced with traffic network congestion, which produces negative effects 
such as longer journey time, increased pollution and noise, increased number of traffic accidents and illegal parking. In response to the existing situation in traffic attempts have been made to implement various mobility management measures with emphasis on the bigger institutions. In Europe many international projects have been started with the aim of improving the mobility of citizens and their daily migrations regardless of the purpose of their movement. Among the most famous are the EU projects: Miracles, EU-MAX, Civitas (Civitas Plus: Archimedes, Mimosa, Renaissance, Elan, Modern), Curacao, Camparie, ELMO, ICARO, INPHORMM, MOST, PROSITrans and numerous others.

The Mobility Management is primarily a demand-oriented approach to passenger and freight transport that involves new partnerships and a set of tools to support and encourage a change of attitude and behaviour towards sustainable modes of transport [7]. These tools are usually based on information and organisation, coordination and require promotion. In the city of Zagreb the Civitas Elan project started in 2008 with the aim of precisely improving urban traffic. One of the structural design measures refers to the management of citizens' mobility focusing on carpooling. Until the start of the Civitas Elan project in the City of Zagreb there had been no systemic implementation of mobility management strategies such as carpooling, car sharing, etc. Carpooling had been mainly sporadically applied at the level of personal acquaintances and usually without sharing of transport costs. The basic aim of introducing carpooling is to carry out efficient and high-quality solution that would provide better mobility of citizens.

Some of the reasons why carpooling has not been realised yet in Zagreb, should be found in the fact that the necessary assumptions had not been realised in order to successfully implement them, and which have been already realised in the majority of countries in which the system functions successfully. There are multiple reasons of developing the concept of shared rides that can be considered from several angles characteristic both for Croatia and for other European countries:

- Overload and reduced capacity of urban roads;

- The citizens expect greater mobility in the cities;

- The majority of countries with a developed traffic system give up the past concept of traffic adjustment to passenger cars and replace it by the concept of active mobility management through alternative transport modes;

- In the city of Zagreb $8.73 \%$ of citizens perform their trips by personal cars as passengers, with an average vehicle occupancy of 1.37 (2009) i.e. 1.40 (2010) [8];

- The studies in Zagreb have shown that bus transport accounts for $50 \%$ of total traffic, passenger cars account for $34.4 \%$ while walking participates with $12.35 \%$ (>100 metres) [8].

Data gathering by means of survey determined the current state of citizens' traffic mobility on the target corridor in the city of Zagreb and to analyse the 
Table 3: Risk management and contingency plans for the introduction of carpooling system in the city of Zagreb.

\begin{tabular}{|c|c|c|c|c|}
\hline Risk type & Risk description & Contingency plan & $\begin{array}{l}\text { Probability } \\
\left(\mathbf{h} / \mathbf{m} / \mathbf{l}^{*}\right)\end{array}$ & $\begin{array}{c}\text { Potential } \\
\text { impact } \\
\left(\mathrm{h} / \mathrm{m} / \mathrm{I}^{*}\right)\end{array}$ \\
\hline Legal & $\begin{array}{l}\text { Possible questions } \\
\text { concerning insurance of } \\
\text { passengers in } \\
\text { carpooling schemes }\end{array}$ & $\begin{array}{l}\text { Explore legal } \\
\text { possibilities }\end{array}$ & $\mathrm{m}$ & $\mathrm{m}$ \\
\hline Financial & $\begin{array}{l}\text { Price of necessary web } \\
\text { application for } \\
\text { carpooling }\end{array}$ & Finding sponsors & $\mathrm{m}$ & $\mathrm{m}$ \\
\hline Technical & $\begin{array}{l}\text { Possible problems in the } \\
\text { work of web } \\
\text { applications }\end{array}$ & $\begin{array}{l}\text { IT professionals } \\
\text { tasked to maintain the } \\
\text { system }\end{array}$ & 1 & 1 \\
\hline Organisational & $\begin{array}{l}\text { Lack of support by } \\
\text { possible user groups } \\
\text { Lack of motivation }\end{array}$ & $\begin{array}{l}\text { Communication } \\
\text { campaign }\end{array}$ & 1 & 1 \\
\hline Political & $\begin{array}{l}\text { Not understanding the } \\
\text { problem }\end{array}$ & $\begin{array}{l}\text { In terms of support } \\
\text { and decision making }\end{array}$ & $\mathrm{m}$ & $\mathrm{m}$ \\
\hline Institutional & $\begin{array}{l}\text { Insufficient cooperation } \\
\text { between involved } \\
\text { partners }\end{array}$ & Regular meetings & 1 & $\mathrm{~h}$ \\
\hline $\begin{array}{l}\text { User } \\
\text { Acceptance }\end{array}$ & $\begin{array}{l}\text { Insufficient number of } \\
\text { users }\end{array}$ & $\begin{array}{l}\text { Communication } \\
\text { campaign, provide } \\
\text { links to carpooling } \\
\text { website from various } \\
\text { sites }\end{array}$ & 1 & $\mathrm{~h}$ \\
\hline Spatial & $\begin{array}{l}\text { Defining area for use of } \\
\text { carpooling scheme } \\
\text { Determining trip origin } \\
\text { carpooling locations in } \\
\text { urban areas }\end{array}$ & $\begin{array}{l}\text { Study will determine } \\
\text { optimal area for use } \\
\text { of carpooling system }\end{array}$ & 1 & 1 \\
\hline
\end{tabular}

* high/medium/low

possible risks in introducing the measures of carpooling. The problems are reflected in the following types of risks: technical, legal, financial, organisational, political, and others. Risk management and contingency plans for the introduction of carpooling system in the city of Zagreb are shown in Table 3. Each of the mentioned risks has numerous characteristics that require comprehensive analysis in order to carry out the measures and improve the traffic capacity in the city.

One of the biggest problems is the absence of adequate legal regulations and decisiveness in bringing such measures that will affect the improvement of traffic at the level of the entire urban traffic network. With the aim of implementing the carpooling system the following drivers and barriers have been noticed (Tables 4 and 5). The drivers and barriers should be considered from several levels, taking into consideration all the stakeholders, and a plan should be made of activities to overcome the barriers and to motivate the drivers. During the target activities the attention should be directed to the management of the available resources (financial, personnel, time, etc.). 
Table 4: The principle overview of drivers in introducing the carpooling system in the city of Zagreb.

\begin{tabular}{|c|c|}
\hline Drivers & \\
\hline \multirow{9}{*}{ Technical } & Planning and improving of urban traffic \\
\hline & Provision of conditions: parking/through capacity \\
\hline & Provision of carpooling system \\
\hline & HOV lanes (High Occupancy Vehicle lanes) \\
\hline & Maintenance i.e. costs of shared rides \\
\hline & Public private partnership \\
\hline & Raising citizens' awareness \\
\hline & Lower need for parking \\
\hline & Existing infrastructure in the city \\
\hline \multirow{9}{*}{ Organisational } & Travel plans (transport plans) \\
\hline & Relevant data \\
\hline & Cooperation among subjects \\
\hline & System support services \\
\hline & Flow of information about activities on the measure \\
\hline & Approach to companies/institutions as traffic generators \\
\hline & Motivation of drivers for using the carpooling system \\
\hline & Include society networks (Facebook, Twitter, etc.) \\
\hline & $\begin{array}{l}\text { Motivate the "drivers" by providing parking (e.g. in the company } \\
\text { area) or by subsidising parking costs }\end{array}$ \\
\hline \multirow{4}{*}{ Financial } & Cost/benefit analysis at personal level \\
\hline & Savings \\
\hline & Covering transport costs for the drivers in the carpooling system \\
\hline & Financial and environmental factors \\
\hline \multirow{7}{*}{ Political } & Harmonisation of legal regulations \\
\hline & $\begin{array}{l}\text { Formation of formal-legal frame for the action of legal and } \\
\text { physical persons who want to engage in carpooling service }\end{array}$ \\
\hline & Understanding of policy carriers \\
\hline & Image of group and individuals \\
\hline & Principle readiness of city structures for cooperation \\
\hline & $\begin{array}{l}\text { Agree with city authorities' free usage of parking places for } \\
\text { "drivers" in the carpooling system or parking reservation. }\end{array}$ \\
\hline & Positive attitude of citizens \\
\hline
\end{tabular}

There are numerous assumptions of successful realisation of carpooling (in the city of Zagreb and Croatia), and one of these is certainly the definition of the notion of carpooling through legal regulations. Interventions are required in the valid Act on Road Transport (N.N. 178/2004) etc. [9].

An efficient establishment of carpooling system in the city of Zagreb requires cooperation and dialogue of all the stakeholders. The first phase of implementation is most easily realised by big and small-size companies or state institutions, and student population, that find the saving that is realised by the 
Table 5: The principle overview of barriers in introducing the carpooling system in the city of Zagreb.

\begin{tabular}{|c|c|}
\hline Barriers & \\
\hline \multirow{7}{*}{ Technical } & $\begin{array}{l}\text { Precise definition of models - technical conditions adapted to } \\
\text { situation and participants }\end{array}$ \\
\hline & Insufficient and unsatisfactory infrastructure \\
\hline & Limited possibilities of infrastructure \\
\hline & Limited parking \\
\hline & $\begin{array}{l}\text { Motivation of citizens to become "drivers" in the carpooling } \\
\text { system }\end{array}$ \\
\hline & Set of traffic priorities for cars in urban traffic \\
\hline & Absence of unique Internet portal for carpooling \\
\hline \multirow{7}{*}{ Organisational } & Harmonisation and communication among users \\
\hline & Compliance with agreed organisational frames \\
\hline & $\begin{array}{l}\text { Lack of information and lack of interest by companies to } \\
\text { introduce carpooling (companies carry out the legal obligation of } \\
\text { covering the transport costs for travelling to work) }\end{array}$ \\
\hline & Determining the starting locations (stops) \\
\hline & Different locations of passengers in the city \\
\hline & Network planning and dispatcher activities \\
\hline & Insufficient parking space \\
\hline \multirow{3}{*}{ Financial } & $\begin{array}{l}\text { Unclear although possible modes of financial stimulation - lack } \\
\text { of exact methods and conditions }\end{array}$ \\
\hline & Vehicle planning for carpooling \\
\hline & $\begin{array}{l}\text { Absence of regulations of cost compensation for cars in the } \\
\text { carpooling system }\end{array}$ \\
\hline \multirow{4}{*}{ Political } & Indifference of relevant city services \\
\hline & Administration and legal base \\
\hline & Car as proof of personal success and exclusivity \\
\hline & Poor image of alternative travel methods \\
\hline
\end{tabular}

alternative transport modes especially interesting. The advantages of alternative travelling methods i.e. carpooling need to be clearly emphasised, such as:

- Significant reduction of travel costs for individual;

- Reduction of air and noise pollution levels and the occupation of public urban areas;

- Possibility of favouring such vehicles in certain situations in traffic (e.g. giving priority on the road, special traffic lane - HOV, priority in parking, partial charging of entering the city, etc.);

- Reduction of traffic congestion;

- Reduction of the load on traffic places;

- Reduction of stress when travelling for passengers who do not drive;

- Enabling integration of several transport modes with a unique fare, etc.

In spite of the mentioned savings and other advantages a plan of additional users' motivation is necessary. The dialogue with the citizens should not be 
neglected, since they represent a corrective agent of the traffic-oriented decisions. By planning and harmonised development of the mobility management of the traffic participants a more efficient detection of the traffic demand can be achieved, thus influencing not only the supply but also a series of harmful consequences resulting from transport.

\section{Conclusion}

Analysis of possible risks in introducing congestion charging and carpooling came to the conclusion that there is a common problem associated with the possible implementation of these measures in the city of Zagreb. When it comes to measure congestion charging in the city of Zagreb, it will still be considered by policy and economic opportunities of the City. Accelerate the matter can be a great acceptability of the proposed charging scheme, which initially will be tight but it will meet its objectives. Technical solutions congestion charging system today is not the problem, but they must be selected to adapt the design of the city. In addition to meeting identified a number of preconditions carpooling system can become one of the default options for travel of citizens of Zagreb.

\section{References}

[1] Statistički ljetopis grada Zagreba, 1990 to 2009.

[2] Bilten o sigurnosti cestovnog prometa (od 1996. do 2008.), Ministarstvo unutarnjih poslova, Zagreb.

[3] Broaddus, A., et al., Transportation Demand Management Training Document, Federal Ministry for Economic Cooperation and Development: Eschborn, Germany, 2009.

[4] Schade, J., Baum, M., "Reactance or acceptance? Reactions towards the introduction of road pricing", Transportation Research Part A, pp. 41-48, 2007.

[5] PRoGRESS project web site, http://www.progress-project.org/

[6] CURACAO, "Deliverable D1: Inception Report", EU-Project CURACAO funded by the European Commission under the 6th Framework Transport RTD, 2006.

[7] European Platform on Mobility Management, http://www.epomm.org/

[8] CIVITAS-ELAN project web site, http://www.civitas.eu/ and http://civitaselan.zagreb.hr/.

[9] Narodne Novine, službeni list RH (Official Gazette) No. 178/2004: Zakon o prijevozu u cestovnom prometu, available at http://narodnenovine.nn.hr/default.aspx. 